\title{
Site selection arahan eksplorasi untuk konservasi ex situ tumbuhan dengan pendekatan spasial di Pulau Bali
}

\author{
Rajif Iryadi $^{*}$ dan Agung Kurniawan ${ }^{1}$
}

'Pusat Penelitian Konservasi Tumbuhan dan Kebun Raya - LIPI

*Email koresponden: masrajifgeo@gmail.com

Direvisi: 2019-11-19 Diterima: 2020-8-25

(C)2020 Fakultas Geografi UGM dan Ikatan Geograf Indonesia (IGI)

\begin{abstract}
Abstrak Kebun Raya "Eka Karya" Bali (KREKB) melakukan eksplorasi tumbuhan di dataran tinggi kawasan timur Indonesia sebagai langkah awal dalam konservasi ex situ tumbuhan. Tujuan studi ini adalah untuk memberikan rekomendasi lokasi eksplorasi tumbuhan di Pulau Bali bagi KREKB. Metode penelitian menggunakan pendekatan analisis SIG berjenjang tertimbang secara spasial danoverlay pada parameter pembatas, yaitu: kawasan hutan dan historis eksplorasi, dengan variabel fisik seperti: bentuklahan, elevasi, tutupan vegetasi, dan penggunaan lahan. Hasil penelitian menunjukkan kawasan hutan di Kabupaten Jembrana (36.576,74 ha) dan Buleleng (32.424,87 ha) merupakan wilayah yang memenuhi kelas direkomendasikan - sangat direkomendasikan untuk eksplorasi tumbuhan. Kondisi lokasi yang sangat direkomendasikan memiliki cakupan yang sempit dengan tantangan medan yang berat, namun berpeluang tinggi untuk mendapatkan tumbuhan prioritas konservasi, baik sebagai koleksi baru maupun terancam kepunahan.
\end{abstract}

Kata kunci: kebun raya, konservasi, eksplorasi, hutan

\begin{abstract}
As one of the main role in plant conservation, Bali Botanic Garden (BBG) has regularly conducted flora expeditions around the mountain areas in the eastern part of Indonesia. This study aimed to provide recommendations for BBG in terms of flora exploration sites in Bali. The methods used GIS analysis approach with spatially weighted tiers with scoring and overlay on the limiting parameters namely forest area and historical exploration, with other physical variables such as landform, elevation, vegetation cover, and land use. The results showed that forest area in Jembrana $(36,576.74 \mathrm{ha})$ and Buleleng $(32,244.87 \mathrm{ha})$ were the areas which met the recommended-highly recommended class for flora exploration. The highly recommended locations characterised by narrow area with a challenging hard terrain, however the chance of obtaining the priority plant for conservation, either new collections or threatened species, is higher.
\end{abstract}

Keywords: botanic garden, conservation, exploration, forest.

\section{PENDAHULUAN}

Bali adalah pulau yang memiliki luasan $5.561 \mathrm{~km}^{2}$ dimana bagaian tengahnya berupa dataran tinggi dengan gunung api seperti Gunung Batur dan Gunung Agung (Göltenboth et al., 2006) serta kawasan Bedugul yang terdapat tiga danau volkan. Kebun Raya "Eka Karya" Bali (KREKB), salah satu dari empat kebun raya yang berada dalam pengelolaan Lembaga Ilmu Pengetahuan Indonesia (LIPI), merupakan lembaga konservasi tumbuhan ex situ yang berdiri tanggal 15 Juli 1959 yang terletak di kawasan Bedugul. Pada awal berdirinya, KREKB berfungsi untuk mengoleksi jenis-jenis Gymnospermae dari seluruh dunia, namun seiring perkembangan waktu menjadi kawasan konservasi ex situ tumbuhan pegunungan tropika kawasan timur Indonesia karena lokasinya berada pada ketinggian $1.250-1.450 \mathrm{mdpl}$, dengan kondisi suhu udara berkisar $18-20^{\circ} \mathrm{C}$ dan kelembapan udara $70-90 \%$ (Siringo Ringo et al., 2019; Darma et al., 2021). Secara umum, di kawasan Bedugul terdapat dua jenis ekosistem hutan yaitu: ekosistem hutan alami dan ekosistem hutan reboisasi (Sutomo et al., 2018).
Kebun raya merupakan salah satu bentuk penyelamatan keanekaragaman hayati Indonesia di luar habitat alaminya (ex situ). Peraturan Presiden RI Nomor 93 Tahun 2011 menyebutkan bahwa kebun raya merupakan kawasan ex situ yang memiliki koleksi tumbuhan yang terdokumentasi (Darma et al., 2021). Sejak tahun 1975 hingga 2018, kegiatan eksplorasi tumbuhan telah terdokumentasi dalam database KREKB. Lokasi eksplorasi tersebar di kawasan timur Indonesia dengan Pulau Bali hampir seluruhnya telah terjelajahi (Kebun Raya "Eka Karya” Bali, 2019). Area di Pulau Bali yang sering menjadi lokasi eksplorasi adalah kawasan konservasi meliputi: Cagar Alam (CA) Batukahu (1.762,8 Ha), Taman Wisata Alam (TWA) Danau Buyan \& Tamblingan (16.950,28 Ha), TWA Panelokan (15.431,44 Ha), TWA Gunung BaturBukit Payang (2.528 Ha), TWA Sangeh (13,91 Ha) (Kebun Raya "Eka Karya” Bali, 2019; Sanjaya, 2020).

Kegiatan eksplorasi tumbuhan dilakukan untuk mengoleksi sekaligus menyelamatkan tumbuhan dari habitat alaminya. Di samping eksplorasi tumbuhan, tugas fungsi kebun 
raya lainnya adalah melakukan perbanyakan material tumbuhan untuk reintroduksi tumbuhan ke habitat aslinya dan restorasi ekosistem, menyediakan material untuk penelitian ilmiah ataupun kegiatan lainnya untuk mengurangi aktifitas pengambilan material tumbuhan secara langsung dari alam, dan juga sebagai alat peraga dalam pendidikan konservasi ataupun sebagai display koleksi tanaman (Havens et al., 2006; BGCI, 2012; Surya et al., 2013; Aplin, 2016; Smith, 2016; Heywood, 2017; Gross, 2018). Oleh karena itu, pengumpulan data floristik dan abiotik bersamaan dengan tumbuhan yang dikoleksi menjadi hal yang penting untuk menunjang beragam fungsi kebun raya di atas.

Menurut laporan terkini, Antonelli et al., (2020) memperkirakan dua dari lima jenis tumbuhan yang ada di bumi terancam kepunahan. Lebih lanjut Purnomo et al. (2015) menyebutkan bahwa Indonesia termasuk dalam lima besar negara dunia dengan flora yang terancam kepunahan. Kawasan hutan Indonesia yang rentan akan bencana kebakaran hutan dan konversi lahan menyebabkan pentingnya antisipasi dalam penyelamatan spesies tanaman-tanaman yang endemik maupun hampir punah. Data per-Oktober 2015 tercatat di Bali terdapat kebakaran hutan seluas 8.5 Ha. (BKSDA, 2015). Sehubungan dengan itu, dewasa ini prioritas tumbuhan yang dikonservasi secara ex situ adalah tumbuhan terancam kepunahan berdasarkan kriteria IUCN Redlist (International Union for Conservation of Nature) yaitu: Critically Endangered (CR), Endangered (EN), dan Vulnerable (VU) (IUCN, 2021). Endemisitas menjadi kriteria penting lainnya dalam penentuan jenis-jenis tumbuhan yang diselamatkan dalam skala lokal. Tingkat endemisitas flora di kepulauan Indonesia dapat mencapai $40-50 \%$ pada setiap pulau, kecuali Pulau Sumatera hanya 23\% (Widjaja, 2014). Salah satu contoh tumbuhan yang berasal dari Bali dan berstatus terancam kepunahan adalah Hopea sangal Korth. (VU) dan Pterospermum blumeanum Korth. (EN) (POWO, 2019; IUCN, 2021).

Permasalahan yang sering terjadi dalam perencanaan eksplorasi adalah pemilihan lokasi eksplorasi, karena data spasial sebaran area eksplorasi belum tertata dengan baik. Pada umumnya, acuan yang digunakan untuk menentukan lokasi eksplorasi tumbuhan adalah data-data lokasi ditemukannya suatu jenis tumbuhan yang terdapat dalam publikasi ilmiah maupun laporan perjalanan eksplorasi (Sutomo, 2014; Wahyuni et al., 2017). Di samping itu, meskipun tingkat akurasi dan validitasnya tidak tinggi, pengetahuan masyarakat lokal ataupun petugas lapangan juga menjadi informasi penting dalam penentuan lokasi eksplorasi tumbuhan. Seiring perkembangan teknologi informasi, penentuan lokasi eksplorasi mulai beralih pada pemanfaatan database online sebagai sumber informasi lokasi geografi tumbuhan seperti kekayaan hayati Indonesia dalam InaBIF (www.inabif.lipi.go.id), Global Biodiversity Information Facility (GBIF) (www.gbif.org), Plant of the World Online (www.plantsoftheworldonline.org), maupun IUCN (www.iucnredlist.org). Namun demikian, database tersebut juga selalu mengalami perubahan dan belum semua data informasi mengenai detail data flora tersedia secara lengkap.

Pemanfaatan Sistem Informasi Geografi (SIG) dalam penentuan site dengan pemanfaatan berbagai parameter fisik lingkungan maupun nilai ekonomisnya dengan pendekatan Analytical Hierarchy Process (AHP) dapat memberikan rekomendasi lokasi yang akan dipilih untuk dibangun ataupun dikembangkan (Tunc et al., 2019). Berbagai pendekatan SIG untuk untuk penentuan lahan potensial dalam penanaman dilakukan dengan pendekatan matching dan scoring (Winarna \& Santoso, 2009). Pendekatan yang sama juga dapat digunakan untuk evaluasi lahan dalam rekomendasi budidaya jenis tumbuhan tertentu dengan melihat autekologinya berdasarkan data lapangan (Sutomo \& Iryadi, 2019). Penelitian ini bertujuan untuk memberikan rekomendasi lokasi yang dapat dipertimbangkan dalam penentuan eksplorasi tumbuhan dengan menggunakan pendekatan spasial kesesuaian habitat KREKB. Penelitian ini menggunakan metode pengharkatan dengan variabel-variabel seperti: tutupan vegetasi, satuan geomorfologi, elevasi, dan penggunaan lahan serta penggunaan data historis lokasi eksplorasi dan data kawasan hutan alami sebagai faktor pembatas. Pulau Bali dipilih sebagai lokasi penelitian karena penelitian ini merupakan yang pertama kali dilakukan untuk menentukan lokasi eksplorasi di Pulau Bali dengan pendekatan spasial. Hasil pendekatan tersebut diharapkan mampu memberikan solusi dalam penentuan lokasi eksplorasi di $\mathrm{Pu}$ lau Bali secara efektif dan meningkatkan peluang penyelamatan jenis-jenis terancam kepunahan termasuk koleksi baru yang belum pernah dimiliki KREKB.

\section{METODE PENELITIAN}

\section{Alat dan bahan}

Data penerimaan material hasil eksplorasi (Data A1) tahun 2003 - 2013 baik itu data hardfile maupun softfile serta data koleksi Kebun Raya "Eka Karya" Bali. Data spasial dengan pemanfaatan data citra Satelit Landsat (resolusi spasial 30 meter) daerah Bali dimana memerlukan tiga scene untuk satu pulau Bali yang diperoleh dari USGS (https:// earthexplorer.usgs.gov/) dan level citra 1b. Kondisi citra yang memiliki coverage tutupan awan dibawah 15\% maka tiga scene citra beda waktu perekaman yaitu: Landsat tahun 2013 (LC81160662013115LGN01), Landsat 2014 (LC81170662014125LGN00) dan Landsat 2015 (LC81160662015217LGN00. Peta Rupa Bumi Indonesia (RBI) Bali digital skala 1:25.000 diakses melalui wbsite Badan Informasi Geospasial (BIG) pada laman https:// tanahair.indonesia.go.id/, data citra SRTM resolusi $30 \mathrm{~m}$ (https://earthexplorer.usgs.gov/), dan Peta Geologi Bali skala 1:250.000 tahun 1971 dari Direktorat Geologi Indonesia. Data lain yang digunakan sebagai data pelengkap adalah data zona hutan tahun 2009 skala 1:600.000 yang diperoleh dari Kementerian Lingkungan Hidup dan Kehutanan. Aplikasi GIS, pengolah data citra, dan seperangkat komputer.

\section{Lokasi penelitian dan data parameter}

Area penelitian melingkupi Pulau Bali, yaitu antara $114^{\circ}$ 25'34" - 115²3'2"BT dan 8²'58" - 8 8 $^{\circ} 2^{\prime} 25^{\prime \prime}$ LS dengan luasan area $5.780,06 \mathrm{~km}^{2}$ dimana $22,9 \%$ areanya merupakan kawasan hutan (BPS Bali, 2021). Kondisi curah hujan wilayah Bali setiap wilayah bervariasi, namun berdasarkan data BPS Bali (2021) rentang curah hujan tahunan sekitar 1.390,5 - 3.070,0 $\mathrm{mm} /$ tahun. Pulau ini secara fisik dibatasi oleh perairan yaitu sebelah utara dengan Laut Bali, sebelah selatan dengan Samudera Hindia, sebelah barat dengan Selat Bali, dan sebelah timur dengan Selat Lombok. Secara administratif, Pulau Bali terdiri atas sembilan Kota/ Kabupaten yaitu: Buleleng, Jembrana, Badung, Denpasar, Gianyar, Bangli, Tabanan, Klungkung dan Karangasem (Gambar 1). Data parameter yang digunakan, yaitu: data lokasi eksplorasi yang pernah dilakukan 
Daerah eksplorasi 2003 -2013

Keterbatasan pengelolaan database dan informasi spasial mengenai sebaran biodiversitas tumbuhan di Indonesia menjadikan proses perolehan data untuk koleksi tumbuhan dilakukan dengan metode jelajah ke kawasan hutan dan metode wawancara untuk mendapatkan informasi jenis tumbuhan yang ditargetkan (Sutomo, 2014). Data lapangan hasil eksplorasi tumbuhan tidak semua terisi secara lengkap. Data penerimaan material hasil eksplorasi (Data A1) berisi data detail jenis tanaman yang berupa: nomor akses spesimen dan kolektor, nama jenis tanaman (ilmiah dan nama daerah), suku, habitus, perbanyakan, jumlah spesimen, lokasi (koordinat dan daerah), kondisi fisik lingkungan serta keterangan lainnya (Warseno \& Iryadi, 2015).

Kurang idealnya kondisi data penerimaan material eksplorasi (Data A1) sebelum tahun 2000, dengan kondisi yang sebagian besar masih berupa catatan manual dan kurang lengkap, menjadi faktor utama dalam penggunaan data tahun 2003-2013. Selain itu, diasumsikan bahwa rentang waktu 10 tahun tersebut dapat memberikan data yang mewakili untuk kajian kandidat lokasi yang perlu dan/atau belum pernah dieksplorasi.

Penyusunan daerah yang belum tereksplorasi membutuhkan data dan informasi historis mengenai lokasi lokasi yang sudah dilakukan eksplorasi. Data informasi untuk daerah yang belum tereksplorasi menunjukkan lokasi prioritas yang dipilih sebagai parameter untuk kegiatan eksplorasi di masa mendatang. Data ini sebagai parameter pembatas untuk menentukan zona eksplorasinya.

\section{Zona Kawasan Hutan}

Zona kawasan hutan diperoleh dari peta zona kawasan hutan daerah Bali. Klasifikasi hutan yang diutamakan adalah hutan yang masih alami. Pemilihan lokasi ini dimaksudkan untuk mendapatkan jenis koleksi tumbuhan asli atau native. Apabila dilakukan pada hutan produksi maupun tutupan lahan non hutan, maka akan banyak sekali jenis tumbuhan hasil budidaya atau bahkan jenis invasif yang bukan jenis tumbuhan asli lokasi tersebut. Dapat dikatakan bahwa jenis tumbuhan yang sama bisa memiliki struktur genetik (DNA)

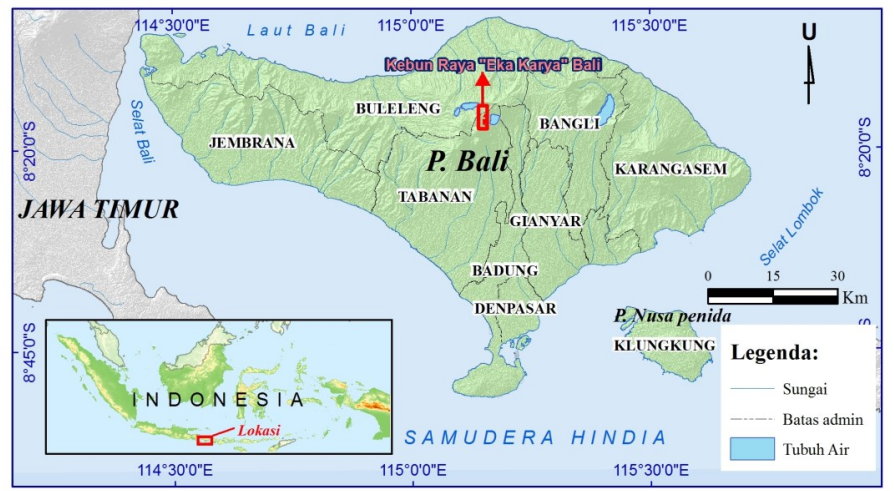

Gambar 1. Lokasi penelitian untuk kajian rekomendasi eksplorasi tumbuhan Pulau Bali

Tabel 1. Kelas area eksplorasi

\begin{tabular}{ll}
\hline Kelas daerah eksplorasi & Skor \\
\hline Daerah yang belum tereksplorasi & 1 \\
Daerah yang sudah dieksplorasi & 0 \\
\hline
\end{tabular}

Sumber: Hasil Pemikiran, 2016 yang berbeda karena pengaruh biogeografinya (Priyadi et al., 2018) sehingga dalam eksplorasi tumbuhan sangat diutamakan mengoleksi tumbuhan yang tumbuh asli di habitat alaminya. Oleh karena itu, prioritas pemilihan lokasi eksplorasi adalah hutan lindung dan cagar alam. Dengan demikian maka kedua kelas tersebut memiliki nilai 1 (satu) karena Tabel 1. Kelas area eksplorasi merupakan prioritas eksplorasi sedangkan untuk kawasan hutan produksi dan/ atau hutan produksi terbatas dinilai 0 (nol) karena bukan prioritas lokasi eksplorasi (Tabel 2).

\section{Tutupan vegetasi}

Data citra satelit yang digunakan adalah data citra satelit Landsat 8 tahun 2013-2014. Penggunaan data citra Landsat digunakan untuk mengekstrak data penutup lahan yang lebih baru. Data tutupan lahan diperoleh dari ekstraksi data citra satelit Landsat OLI tahun 2014. Penggunaan citra satelit terdiri atas citra Landsat Bali barat (satu perekaman) dan Bali timur (dua perekaman yang berbeda tanggal) karena permasalahan tutupan awan wilayah yang terekam oleh satelit. Klasifikasi dengan menggunkan klasifikasi tak terbimbing dengan metode iso-data dengan mengatur jumlah kelas 15 kelas dan pengulangan (itterasi) 5 kali proses, penggunaan klasifikasi ini lebih efesien karena data yang diperlukan adalah data tutupan vegetasi. Definisi klasifikasi tutupan vegetasi data citra satelit untuk mengidentifikasi dan interpretasi jenis kelas tertentu ke kelas yang diinginkan berdasarkan objek yang nampak di citra. Objek yang diutamakan adalah informasi data tutupan lahan vegetasi. Variabel tutupan vegetasi merupakan variabel yang menentukan ada tidaknya tumbuhan sebagai objek dan indikasi adanya target dalam kegiatan eksplorasi tumbuhan. Diharapkan tujuan eksplorasi tumbuhan adalah mengambil objek tumbuhan itu sendiri sehingga analogi dalam penilaian kelas yang bervegetasi memiliki skor 1 (satu) sedangkan yang tidak bervegetasi akan dinilai 0 (nol) (Tabel 3). Klasifikasi yang awalnya terkelaskan menjadi 15 kelas spesifikasi objek hasil klasifikasi digital dipersempit menjadi dua kelas utama secara visual (Predotti, 2012) yaitu lihat tabel 2.

\section{Satuan bentuklahan wilayah}

Data SRTM (Suttle Radar Topography Mission) apabila digabungkan dengan data dari landsat dan peta geologi akan menurunkan data geomorfologi wilayahnya. Pengukuran data untuk skoring dilakukan dengan pendekatan deduktif

Table 2. Status Kawasan

\begin{tabular}{llc}
\hline Jenis hutan & Kelasifikasi & Skor \\
\hline Hutan Lindung & Hutan alami & 1 \\
Kawasan Cagar Alam & Hutan alami & 1 \\
Hutan Produksi Terbatas & Hutan produksi & 0 \\
Hutan Produksi & Hutan produksi & 0 \\
\hline
\end{tabular}

Sumber: Hasil Pemikiran, 2016

Tabel 3. Kelas Tutupan Vegetasi

\begin{tabular}{ll}
\hline Kelas vegetasi & Skor \\
\hline Tak bervegetasi & 0 \\
Bervegetasi & 1 \\
\hline
\end{tabular}

Sumber: Hasil Pemikiran, 2016 
dimana setiap satuan unit geomorfologinya dilakukan penjabaran baik dari unsur lereng, kondisi sungai, interpretasi tebal solum tanah sampai ke pendekatan wilayah regional eksplorasi (van Zuidam, 1978). Suatu kawasan memiliki ciri khas geomorfoologi yang berbeda-beda sehingga dalam penyusunan satuan bentuklahan dengan mempertimbangkan geomorfologi wilayah tertentu. Pengkelasan dan penentuan nilai dalam konteks karakter spasial data dapat menggunakan tabel visualisasi (Zuca et al., 2007). Kebun Raya "Eka Karya" Bali (KREKB) dibangun dan didesain untuk konservasi tumbuhan ex situ pegunungan lahan kering. Pendekatan bentuklahan kesesuaian didasarkan pada lokasi KREKB yang berada di kawasan pegunungan lereng gunung api (bentuklahan volkan), sedangkan interpretasi solum tanah hasil deduktif dengan penjabaran detail sebelumnya diasumsikan lokasi yang memiliki solum tanah tipis-tebal dimungkinkan dapat tumbuh tanaman. Selanjutnya dapat dikelaskan ke habitat yang mungkin dapat tumbuh jika ditanaman di KREKB dengan nilai 1 (satu), tanpa perlu perlakuan khusus atau rekayasa penanaman seperti aklimatisasi dalam rumah kaca, sedangkan yang habitatnya tidak sesuai dinilai 0 (nol) karena jika dipaksakan ditanam di KREKB maka tumbuhan akan mati atau memerlukan upaya keras (biaya dan lokasi perlakuan). Tabel visualisasi spasial ini akan menurunkan kecocokan habitat tumbuhan (Tabel 4).

\section{Penggunaan lahan}

Data penggunaan lahan dapat diperoleh dari data peta RBI (Rupa Bumi Indonesia) skala 1: 25.000. Kelas penggunaan lahan dilakukan pemilihan dan pengelompokan menjadi 4 kelas dengan memperhatikan kondisi penggunaan lahan yang belum mengalami perubahan peruntukan dan pemanfaatan lahan. Selain data peta kawasan hutan yang secara area dan batasannya juga sudah jelas, penentuan data penggunaan lahan dari RBI lebih memperjelas tujuan eksplorasi. Kelas hutan rimba diharapkan memberikan peluang akan tingginya komposisi biodiversitas tumbuhan, sebaliknya semak belukar dan padang rumput berpotensi terjadi penurunan komposisi jenis tumbuhan (Badzlina et al., 2019) sehingga analogi pengkelasan dapat dikategorikan menjadi empat kelas dengan nilai skor yang berbeda (Tabel 5). Data peta RBI lebih menekankan pada pemilihan lokasi penggunaan lahan yang memang layak untuk dijadikan lokasi eksplorasi. Pengecualian diberlakukan untuk hutan bakau, karena jenis tumbuhan vegetasi pantai tidak sesuai dengan habitat KREKB sehingga dimasukan ke penggunaan lahan lainnya.

\section{Zona elevasi}

Data elevasi diperoleh dari data citra SRTM (Suttle Radar Topography Mission) resolusi $30 \mathrm{~m}$. Kelas elevasi dibagi menjadi enam kelas interval elevasi setiap $500 \mathrm{mdpl}$ (Tabel 6) agar variasi elevasi yang tidak begitu besar dapat mencerminkan variasi komposisi tumbuhan yang akan dieksplorasi. Faktor utama yang mempengaruhi vegetasi pegunungan adalah: elevasi, aktivitas vulkanik, status nutrisi tanah, cuaca, dan ketinggian awan (Göltenboth et al., 2006). Karakteristik tumbuhan pegunungan dipengaruhi oleh elevasi tumbuhnya vegetasi sehingga memunculkan zona tumbuhan permanen yang akan menyebar ke bagian batas atas

Tabel 4. Kelas Satuan Bentuklahan

\begin{tabular}{|c|c|c|c|}
\hline BL Utama & Detail BL & $\begin{array}{l}\text { Solum } \\
\text { Tanah }\end{array}$ & Habitat \\
\hline \multirow[t]{12}{*}{ Vokanik } & Creater & - & - \\
\hline & Kerucut gunung api I & Tipis - tebal & $\begin{array}{l}\text { Memungkinkan ditanam di Kebun Raya } \\
\text { Bali }\end{array}$ \\
\hline & Kerucut gunung api II & - & - \\
\hline & Baranco & Tipis - tebal & Memungkinkan ditanam \\
\hline & Aliran lava & Tipis - sedang & Memungkinkan ditanam \\
\hline & Padang lava & Tipis - sedang & Memungkinkan ditanam \\
\hline & Danau volkan & - & - \\
\hline & Lereng gunung api atas & Sangat tipis - sedang & Memungkinkan ditanam \\
\hline & Lereng gunung api tengah & Tipis - tebal & Memungkinkan ditanam \\
\hline & Dataran antar gunung api & Sedang & Memungkinkan ditanam \\
\hline & Dataran fluvio volkan & Tipis - tebal & Memungkinkan ditanam \\
\hline & Bukit sisa & Tipis & Memungkinkan ditanam \\
\hline \multirow[t]{3}{*}{ Fluvial } & Dataran fluvial & Tebal & Memungkinkan ditanam \\
\hline & Dataran alluvium & Tebal & Memungkinkan ditanam \\
\hline & Endapan alluvium volkan & Sedang & Memungkinkan ditanam \\
\hline \multirow[t]{4}{*}{ Denudasional } & Kipas koluvium & Tebal & Memungkinkan ditanam \\
\hline & Perbukitan denudasional & Tipis - sedang & Memungkinkan ditanam \\
\hline & Lereng kaki perbukitan denudasional & Tipis - tebal & Memungkinkan ditanam \\
\hline & Bukit rombakan & Tipis - sedang & Memungkinkan ditanam \\
\hline \multirow[t]{3}{*}{ Solusional } & Perbukitan karst & Tipis - sedang & Kurang sesuai \\
\hline & Dataran karst & Tebal & Kurang sesuai \\
\hline & Formasi karst lainnya & Tipis - sedang & Kurang sesuai \\
\hline \multirow[t]{2}{*}{ Marine } & Dataran marine & Tebal & Kurang sesuai \\
\hline & Dataran Fluvio marine & Tebal & Kurang sesuai \\
\hline
\end{tabular}


maupun bawah zona tersebut namun dapat mengakibatkan variasi morfologi tumbuhan tertentu bahkan menjadi infertile (Gambar 2) (Whitten et al., 1996). Disebutkan pula bahwa kondisi suhu tanah dan kelembaban yang diakibatkan ketinggian maupun perubahan iklim mempengarihi komposisis diversitas tumbuhan bahkan eksistensinya (Niu et al., 2019; Malanson et al., 2019).Posisi elevasi KREKB berada pada kelas zona elevasi antara 1001 - 1500 mdpl. Kesesuaian karakteristik vegetasi lebih diutamakan pada zona ini karena peluang hidup dan adaptasi tumbuhan yang dikumpulkan akan lebih baik. Dalam hal rekomendasi zona elevasi eksplorasi ada di kelas zona terdekat dari zona yang paling diutamakan.

\section{Analisa data}

Pendekatan yang digunakan adalah analisis spasial satuan pemetaan dari masing-masing parameter yang digunakan dengan melakukan overlay berjenjang tertimbang dengan analisis skoring dari variabel yang telah diklasifikasikan dan dibobotkan sesuai dengan pengaruh yang signifikan dalam menentukan lokasi suatu wilayah eksplorasi. Variabel yang paling menentukan adalah daerah yang belum dieksplorasi dan kawasan hutan, karena berfungsi sebagai parameter pembatas lokasi yang akan dieksplorasi. Parameter pembobotan yang besar adalah data tutupan vegetasi, sedangkan data satuan geomorfologi lahan (hasil interpretasi citra landsat dan data peta geologi) memegang peran kontrol tumbuhtumbuhan sebagai lahan tempat tumbuhnya. Data penggunaan lahan dan zona elevasi sebagai variabel penunjang untuk kesesuaian dalam pemilihan lokasi yang dilakukan eksplorasi (Gambar 3).

Pendekatan yang digunakan dari empat parameter dan dua parameter pembatas tersebut dilakukan secara pemberian skoring berdasarkan hierarki yang sesuai dengan kondisi fisiknya (Fathurahman \& Maliki, 2018), sesuai dengan tiap kelas variabel yang telah dibuat sebelumnya dan dilakukan analisis overlay dengan berjenjang tertimbang. Penyusunan zona eksplorasi menggunakan data historis daerah eksplorasi dan daerah hutan alami berfungsi sebagai variabel pembatas untuk memfokuskan lokasi pada kawasan hutan alami dan area yang belum tereksplorasi. Selain itu, parameter lahan yang bervegetasi memiliki prioritas utama

Tabel 5. Kelas penggunaan lahan (PL)

\begin{tabular}{ll}
\hline Keterangan & Skor \\
\hline Hutan Rimba & 3 \\
Semak belukar/ Alang-alang & 2 \\
Padang rumput & 1 \\
PL lainnya & 0 \\
\hline
\end{tabular}

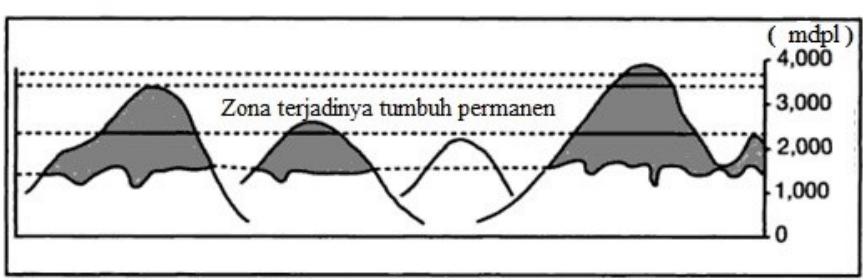

Gambar 2. Zona kejadian tumbuh permanen pada vegetasi pegunungan dan hipotesis distribusi spesies (abu-abu)

(Whitten et al., 1996).
Tabel 6. Kelas elevasi

\begin{tabular}{|c|c|c|}
\hline $\begin{array}{l}\text { Zona elevasi } \\
\text { (mdpl) }\end{array}$ & Keterangan & Skor \\
\hline $0-500$ & $\begin{array}{l}\text { Tanaman Koleksi } \\
\text { kemungkinan } \\
\text { hidup rendah/ } \\
\text { merana }\end{array}$ & 1 \\
\hline $501-1000$ & $\begin{array}{l}\text { Tanaman Koleksi } \\
\text { kemungkinan } \\
\text { hidup sedang }\end{array}$ & 2 \\
\hline $1001-1500$ & $\begin{array}{l}\text { Tanaman Koleksi } \\
\text { kemungkinan } \\
\text { hidup tinggi }\end{array}$ & 3 \\
\hline $1501-2000$ & $\begin{array}{l}\text { Tanaman Koleksi } \\
\text { kemungkinan } \\
\text { hidup sedang }\end{array}$ & 2 \\
\hline $2001-2500$ & $\begin{array}{l}\text { Tanaman Koleksi } \\
\text { kemungkinan } \\
\text { hidup rendah/ } \\
\text { merana }\end{array}$ & 1 \\
\hline $2501-3000$ & $\begin{array}{l}\text { Tanaman Koleksi } \\
\text { kemungkinan } \\
\text { mati tinggi/ perlu } \\
\text { perlakuan khusus }\end{array}$ & 0 \\
\hline
\end{tabular}

Sumber: Hasil Pemikiran, 2017

sebagai lokasi yang dipilih sehingga memiliki pengharkatan paling tinggi, yaitu 3 (tiga) dan satuan bentuklahan mengikuti diurutan kedua dengan nilai harkat 2 (dua) untuk parameter lainnya memiliki harkat 1 (satu) (persamaan 1). Hasil overlay data parameter tersebut dilakukan pengkelasan data rekomendasi eksplorasi tumbuhan berdasarkan klasifikasi skala interval dari nilai total hasil skor penggabungan, menjadi: tidak direkomendasikan (St/ skor total: 0-5), direkomendasikan (St: 6-10), dan sangat diromendasikan (St $>10)$. Formulasi pengharkatan untuk mendapatkan skor total adalah:

$S t=((3 x S v)+(2 x S b l)+S e+S p l)) x(S h x) x(S k h)$

Dimana: St: Skor total; Sv: Skor tutupan vegetasi; Sbl: Skor satuan bentuklahan; Se: Skor elevasi; Spl: Skor penggunaan lahan; Shx: Skor historis eksplorasi tumbuhan; Skh: Skor kawasan hutan

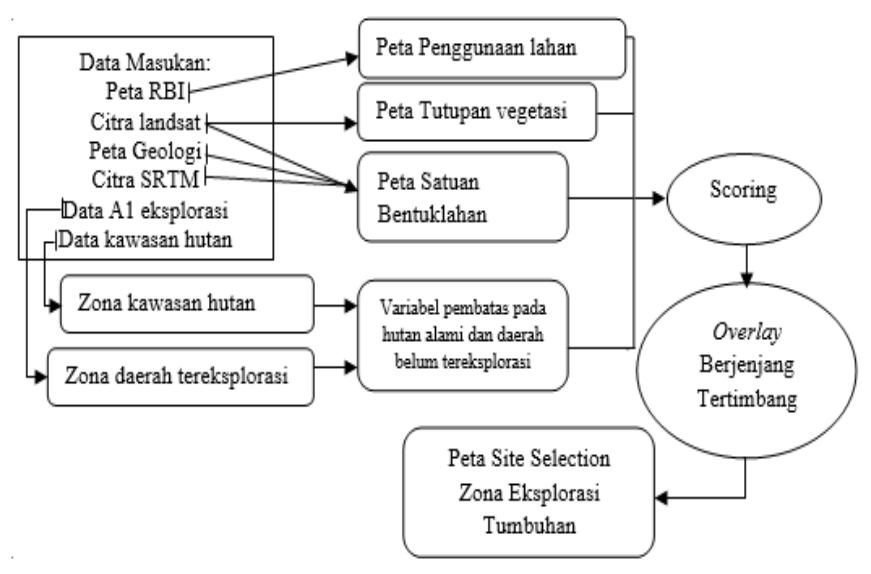

Gambar 3. Diagram alur penelitian 


\section{HASIL DAN PEMBAHASAN}

Berdasarkan hasil monitoring ketersediaan data hasil eksplorasi yang sudah terorganisir dengan baik, data penerimaan material hasil eksplorasi tahun 2012 - 2015 dapat digunakan untuk melihat gambaran perolehan koleksi hidup termasuk capaian koleksi baru yang belum dimiliki Kebun Raya "Eka Karya Bali (KREKB). Terlihat pada rentang waktu tersebut dari total 1128 nomor tanaman hasil eksplorasi, 112 nomor merupakan koleksi baru bagi KREKB (Gambar 4).

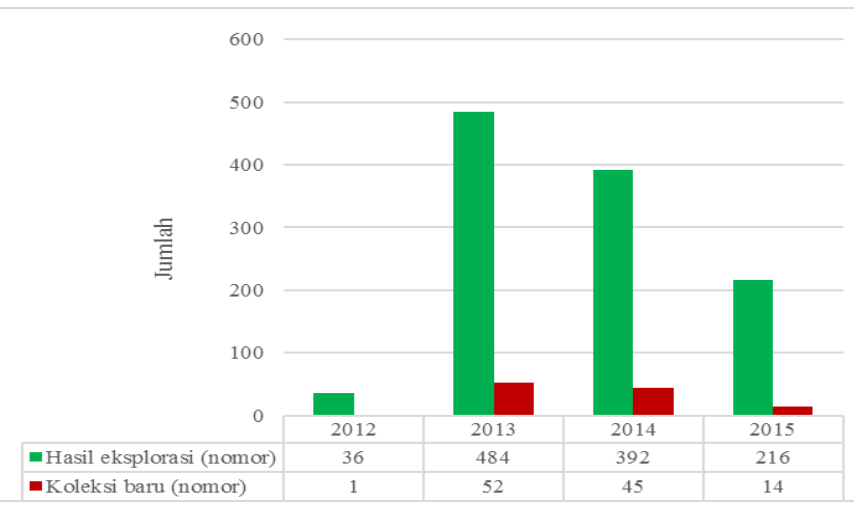

Gambar 4. Grafik perolehan material eksplorasi tumbuhan 2012-2015 Kebun Raya “Eka Karya” Bali (Sumber: Kebun Raya “Eka Karya” Bali, 2015).

Perolehan data koleksi material tumbuhan hidup salah satunya diperoleh melalui kegiatan eksplorasi pada kawasan hutan yang masih alami. Jumlah perolehan koleksi baru tiap tahunnya dipengaruhi oleh variasi dan jumlah daerah eksplorasi yang dilakukan. Gambar 4 memperlihatkan perbandingan lokasi eksplorasi, pada tahun 2012 dilakukan di satu lokasi saja yaitu Kalimantan, sedangkan tahun 2013 di tiga, lokasi yaitu: di Kalimantan, Sulawesi, dan Maluku. Jumlah daerah eksplorasi dipengaruhi oleh anggaran dan kebijakan lembaga, pengaruh tenaga peneliti dan/atau parataksonom yang memiliki keahlian pengenalan jenis tumbuhan yang akan dikoleksi. Kondisi seperti ini menggambarkan capaian jumlah koleksi baru yang rendah dengan rata -rata 9,9\% jenis tumbuhan dalam jangka waktu 4 tahun (Gambar 4).

Konservasi ex situ bertujuan untuk melestarikan jenisjenis tumbuhan yang sudah jarang kelimpahannya di alam, yang nantinya akan dibudidayakan di KREKB untuk mendapatkan bibit optimal yang nantinya akan dikembalikan lagi ke habitat semula (Sujarwo, 2013). Oleh karena itu, prioritas target jenis tumbuhan koleksi juga perlu diperhatikan, namun ketersediaan database flora Indonesia sendiri masih sangat terbatas dan untuk jenis-jenis dengan tujuan tertentu memakan waktu lama saat ditelusur. Mengacu pada data keterancaman IUCN Redlist, hampir 17\% dari 9441 jenis tumbuhan koleksi KREKB terdaftar dalam IUCN Redlist (Tabel 7). Mayoritas sebesar 83,38\% masih berstatus $\mathrm{NE}$ atau belum dilakukan evaluasi. Sebanyak 100 jenis tumbuhan atau tidak lebih dari $2 \%$ adalah jenis-jenis tumbuhan yang terancam kepunahan yang berstatus EW, CR, EN, dan VU.

Dalam hal sasaran penelitian adalah tumbuhan dalam kawasan dengan tutupan vegetasi alami maka skala penggunaan data yang digunakan memiliki kualitas detail untuk skala kecil atau regional. Parameter pembatas yang
Tabel 7. Status jenis konservasi tumbuhan berdasarkan data IUCN 2021

\begin{tabular}{ccc}
\hline & $\begin{array}{c}\text { Jumlah spesies } \\
\text { Tumbuhan }\end{array}$ & Persentse \\
\hline Status conservasi & 0 & $0 \%$ \\
Extinct $(\mathrm{E})$ & 1 & $0,01 \%$ \\
Extinct in the wild (EW) & 16 & $0,17 \%$ \\
Critical endangered (CR) & 43 & $0,46 \%$ \\
Endagered (EN) & 40 & $0,42 \%$ \\
Vulnerable (VU) & 52 & $0,55 \%$ \\
Near treatened (NT) & 1.299 & $13,76 \%$ \\
Least concern $(\mathrm{LC})$ & 118 & $1,25 \%$ \\
Data Deficient $(\mathrm{DD})$ & 7872 & $83,38 \%$ \\
Not evaluated (NE) & 9441 & $100 \%$ \\
Total &
\end{tabular}

Sumber: Data olah koleksi katalog buku kebun KREKB dengan database IUCN per Juni 2021

digunakan adalah data kawasan hutan dan historis area yang telah tereksplorasi. Data kawasan hutan bersumber dari Kementerian Lingkungan Hidup dan Kehutanan sebagai rujukan batasan wilayah yang merupakan zona hutan alami. Kondisi hutan di Bali dengan area hutan terluas adalah Bali bagian barat yang dimulai dari Taman Nasional Bali Barat dan Hutan Lindung bagian tengah Bali yang terletak di antara Kabupaten Buleleng dan Jembrana (Gambar 5).

Catatan dan data yang terekam pada dokumen penerimaan material hasil eksplorasi tumbuhan KREKB dalam rentang waktu tahun 2003-2013 diinventarisasi dengan memploting area yang telah dieksplorasi (Gambar 6). Data yang berhasil dihimpun dari historis eksplorasi tumbuhan tidaklah ideal, hanya berupa sebaran titik-titik koordinat

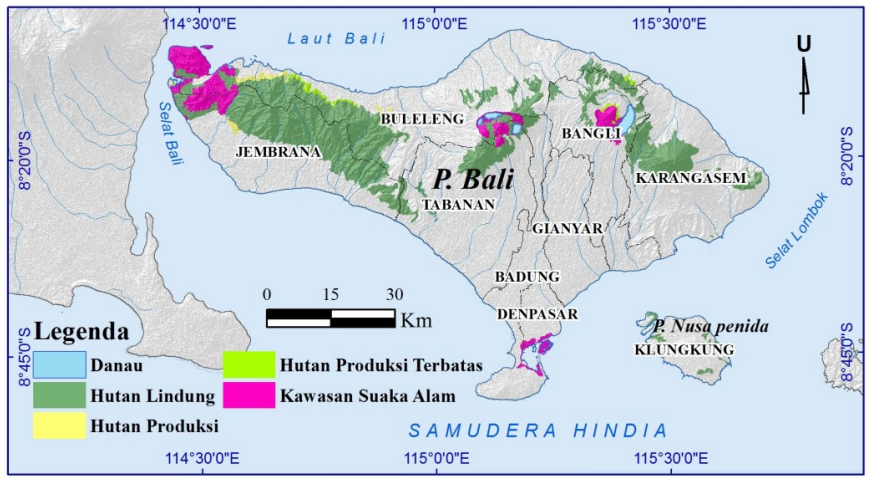

Gambar 5. Peta kawasan hutan Bali

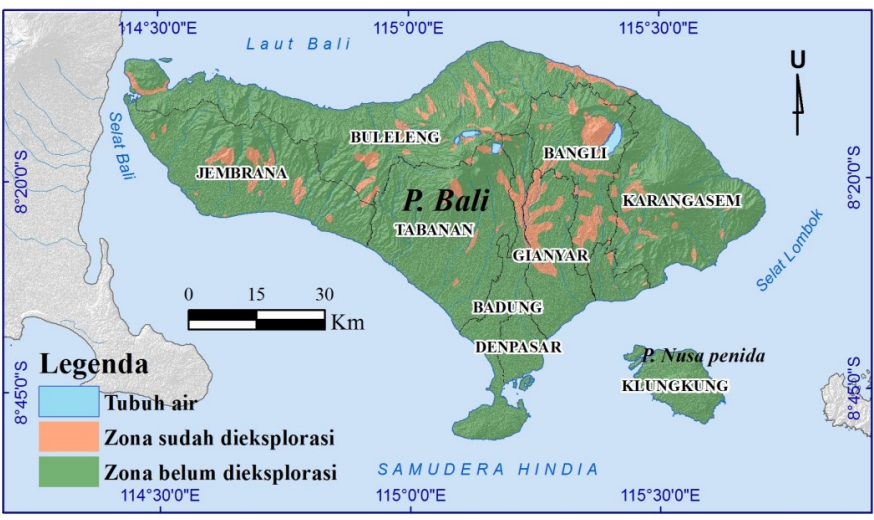

Gambar 6. Zonasi area tereksplorasi. 


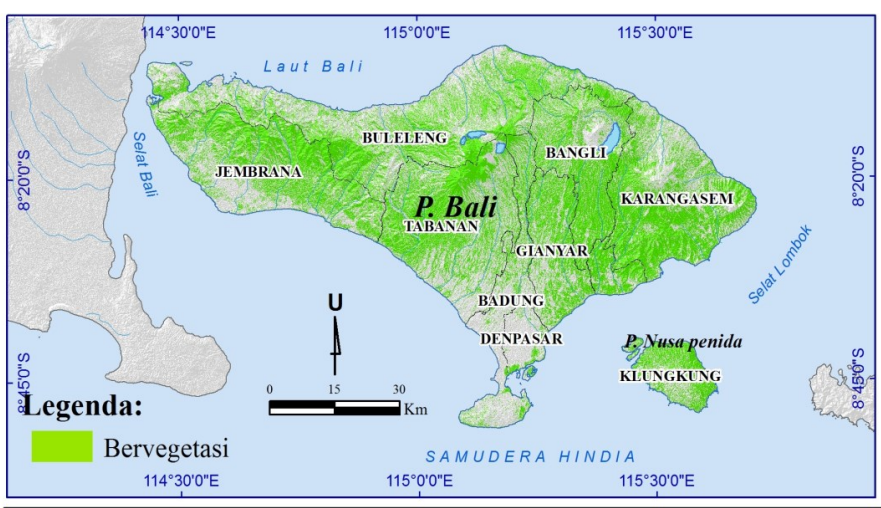

Gambar 7. Peta Tutupan vegetasi Bali

GPS ataupun jalur transek. Pendekatan satuan unit, apabila lokasi koordinat tidak tercatat, digunakan satuan unit desa sebagai catatan lokasi eksplorasi. Dalam kurun waktu 20032013 dapat terlihat perkembangan eksplorasi tumbuhan di Pulau Bali. Lokasi yang telah dieksplorasi didominasi daerah Bali bagian tengah dan timur yaitu: Kabupaten Tabanan, Kabupaten Bangli, Kabupaten Gianyar, dan Kabupaten Karangasem. Kabupaten Buleleng, dengan luasan wilayah terbesar, memiliki daerah lokasi eksplorasi yang masih minim. Lokasi-lokasi tersebut umumnya dilakukan di area non hutan seperti kebun dan ladang penduduk. Hal ini terjadi karena dalam periode tersebut, sebagian besar target kegiatan eksplorasi tumbuhan di Pulau Bali adalah tanaman upacara agama Hindu dan tanaman obat tradisional Bali. Area non hutan berpotensi tinggi dipengaruhi oleh aktivitas masyarakat, adanya tumbuhan invasif maupun tumbuhan reintroduksi lainnya yang bukan asli dari daerah tersebut (Widjaja et al., 2014).

Keberadaan vegetasi memiliki peranan sangat penting dalam kelestarian ekosistem (Predotti, 2012). Informasi terkini mengenai ada tidaknya tutupan vegetasi alami di $\mathrm{Pu}-$ lau Bali diperlukan untuk mengetahui target lokasi eksplorasi. Parameter tutupan vegetasi secara cepat dan terbaru diperoleh dari data citra satelit digital Landsat. Pulau Bali tidak semua wilayahnya terpenuhi dalam satu scene perekaman, namun terdapat tiga scene citra Landsat. Ketersediaan data Landsat yang bersih awan adalah data tahun 2013, 2014 dan 2015. Informasi interpretasi tutupan vegetasi berdasarkan citra Landsat (Predotii, 2012) dengan kerapatan tinggi hingga sedang diprioritaskan sebagai target lokasi eksplorasi. Pulau Bali memiliki $\pm 53 \%$ area tertutup vegetasi dari keseluruhan wilayahnya dan berupa kawasan hutan (Gambar 7). Kondisi hutan Pulau Bali memiliki kawasan hutan alami (Hutan Lindung dan Kawasan Cagar Alam) sekitar $\pm 131.884 \mathrm{Ha}$ atau sekitar $\pm 23,58 \%$ dari luasan pulau.

Data penggunaan lahan merupakan parameter yang memberikan informasi status penggunaan lahan yang ada di kawasan penelitian. Informasi penggunaan lahan pada peta Rupa Bumi Indonesia (RBI) memberikan informasi detail jenis tutupan suatu vegetasi. Hutan alami merupakan tempat ideal sebagai lokasi eksplorasi tumbuhan dibandingkan dengan semak belukar bahkan rerumputan, karena lokasi hutan alami mencerminkan keanekaragaman biodiversitas tumbuhan yang tinggi (Badzlina et al., 2019). Beberapa informasi menunjukkan bahwa area padang rumput dan semak belukar tersegmentasi secara jelas sehingga dapat berfungsi sebagai kontrol untuk parameter tutupan vegetasi hasil dari klasifikasi citra Landsat sebelumnya (Gambar 8). Data penggunaan lahan RBI selanjutnya diperbaharui (detail up-

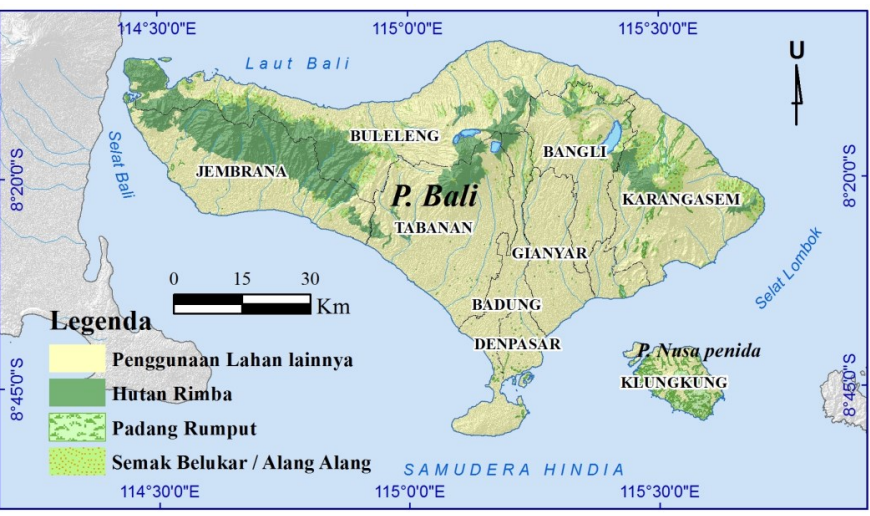

Gambar 8. Peta penutup lahan pada kawasan hutan Bali

date) dengan data citra satelit tahun 2013-2015 dari kelas tutupan vegetasi hasil interpretasi. Hutan Rimba kawasan Bali terluas pada daerah tengah bagian barat yaitu perbatasan Kabupaten Jembrana dan Buleleng.

Geomorfologi lahan kawasan penelitian didominasi oleh area volkan (gunung api) yang memiliki tingkatan elevasi perbukitan sampai bergunung. Formasi di Pulau Bali termasuk dalam kawasan vulkanik Sumatera-Jawa-Nusa Tenggara (Verstappen, 2013). Hal ini mengakibatkan karakter bahan indukan material tanah antara lokasi yang tinggi dan rendah berbeda baik itu tingkat kandungan kimia maupun sifat fisik tanahnya yang merupakan media untuk tumbuhan (Whitten et. al., 1996). Semakin tinggi topografi maka kondisi kelerengan akan semakin terjal dan dalam proses pembentukan topsoilnya juga akan terbatas. Suhu udara juga akan berubah dengan adanya perubahan elevasi. Suhu akan menurun seki$\operatorname{tar} 0.6^{\circ} \mathrm{C}$ ketika elevasi suatu tempat bertambah $100 \mathrm{mdpl}$ (Göltenboth et al., 2006). Daerah Bali tengah sampai timur didominasi oleh bentuklahan volkan, bagian barat merupakan perbukitan denudasional karena tersusun atas perbukitan sisa pegunungan lipatan, pegunungan kompleks, dataran nyaris terdeformasi, dan pengangkatan akibat faktor tektonik dan juga faktor klimatik (Verstappen, 2013) (Gambar 9). Kondisi fisik wilayah Bali utara dan selatan berbeda karena dipengaruhi oleh kondisi fisik dimana pegunungan Bali utara memiliki lereng tajam menuju ke laut, dengan dataran pesisir yang sempit (Göltenboth et al., 2006). Selain itu, menurut Setiawan (2012), mengacu pada klasifikasi Schmidht-Fergusson, kadar curah hujan wilayah Bali selatan dengan kelas B-C (basah- agak basah), lebih tinggi dibandingkan dengan Bali utara dengan kelas D-E (sedang agak kering). Satuan unit lahan yang didasarkan pendekatan geomorfologi memberikan gambaran mengenai interpretasi tebal soil tanah untuk menentukan peluang suatu tumbuhan untuk hidup di wilayah tersebut.

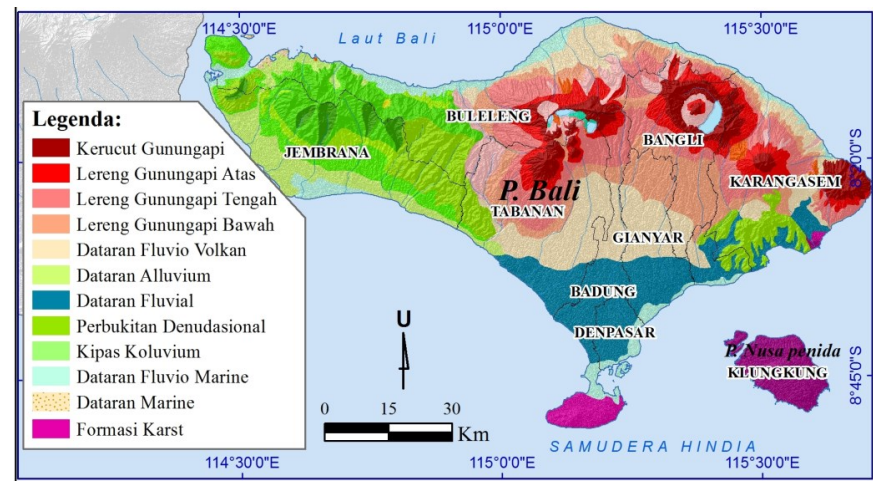

Gambar 9. Peta Bentuklahan Bali 
Elevasi Pulau Bali diperoleh dari data DEM citra SRTM dengan melakukan pengkelasan selisih per-kelas $500 \mathrm{mdpl}$. Merujuk pada lokasi KREKB yang berada pada kelas 1001 1500 mdpl, menunjukkan karakter dan target material hasil eksplorasi merupakan tumbuhan yang dapat beregenerasi pada kawasan kelas lereng tersebut. Tumbuhan hasil eksplorasi akan menjalani masa aklimatisasi sebelum ditanam di petak-petak koleksi. Proses aklimatisasi dilakukan agar tumbuhan dapat beradaptasi dengan kondisi lingkungan yang baru dengan perbedaan ketinggian tempat, unsur hara, cuaca, iklim, dan curah hujan. Karakter hutan pada zona elevasi 1001 - 1500 mdpl merupakan kawasan hutan pegunungan rendah dimana dalam perkembangan tingkat biodiversitas dan ekosistem tumbuhannya akan mempengaruhi variasi pada kelas elevasi bagian atas maupun bawahnya secara nyata (Whitten et al., 1996). Sehingga kelas elevasi yang berdekatan dengan kelas tipe lokasi KREKB akan memiliki nilai yang lebih tinggi dibanding dengan lokasi yang kelas elevasinya jauh dari tipe elevasi KREKB. Dominasi kelas elevasi yang cukup sesuai untuk eksplorasi tersebar dari wilayah Bali barat sampai ke timur khususnya bagian tengah Pulau Bali (Gambar 10).

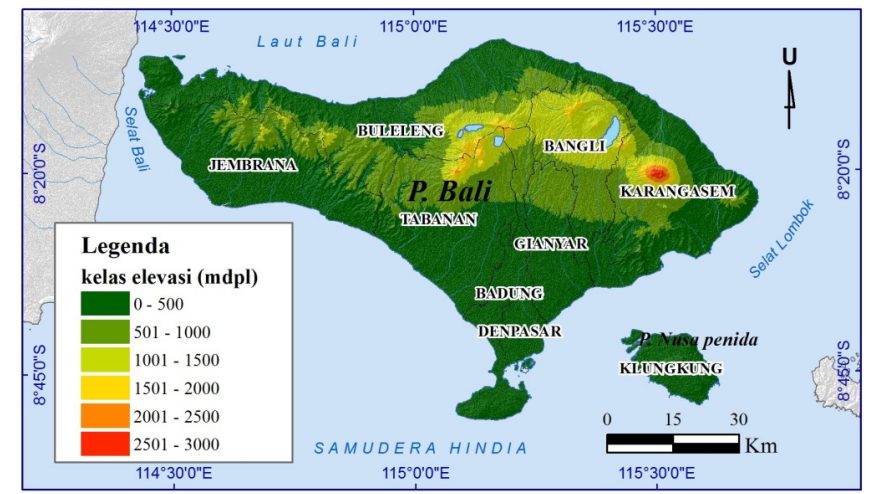

Gambar 10. Peta kelas elevasi daerah Bali

Proses penyusunan arahan lokasi eksplorasi tumbuhan ini lebih mengacu pada kondisi fisik lahan dan kondisi tutupan vegetasinya. Hasil penentuan kawasan eksplorasi ini berupa zonasi area yang "sangat direkomendasikan" sampai "tidak direkomendasikan". Kawasan hutan yang tidak direkomendasikan menjadi tempat eksplorasi tumbuhan adalah kawasan hutan bakau di Denpasar yang merupakan kawasan pesisir, beberapa kawasan di kerucut gunung api, sebagian besar kawasan pulau Nusa Penida walaupun ada sebagian kecil lokasi yang direkomendasikan, dan sebagian besar kawasan Taman Nasional Bali Barat (TNBB). Area pesisir pantai TNBB tidak direkomendasikan namun beberapa lokasi yang memiliki relief berbukit direkomendasikan untuk lokasi eksplorasi tumbuhan. Secara administratif, Kota Denpasar dan Kabupaten Gianyar tidak memiliki lokasi yang direkomendasikan untuk eksplorasi tumbuhan. Kawasan yang sangat direkomendasikan untuk dilakukan eksplorasi tumbuhan terdapat pada bagian tengah Pulau Bali meliputi Kabupaten Buleleng, Jembrana, Tabanan, Bangli, dan Karangasem (Gambar 11).

Komposisi lokasi yang sangat direkomendasikan memiliki cakupan yang sempit denga akses lokasi yang cukup berat, mengingat lokasi tersebut memiliki morfologi wilayah pegunungan khususnya Kecamatan Mendoyo (Jembrana) serta Kecamatan Seririt dan Gerokgak (Buleleng) yang ter- letak pada perbatasan Kabupaten Jembrana dan Buleleng. Komposisi area rekomendasi tertinggi untuk kegiatan eksplorasi tumbuhan dengan kelas "direkomendasikan" hingga "sangat direkomendasikan", meliputi area yang luas yaitu: Kabupaten Jembrana (total area 36.576,74 ha) dan Buleleng (total area 32.424,87 ha) (Gambar 12). Kemudian disusul oleh Kabupaten Karangasem (10.987,06 ha), Tabanan (8.469 ha ) dan Bangli (6.061,23 ha) yang memiliki cakupan bagian wilayah eksplorasi yang lebih rendah. Kabupaten Badung yang pesat dengan pembangunan wilayah, masih menyisakan wilayah yang direkomendasikan - sangat direkomendasikan untuk eksplorasi tumbuhan, yaitu di Kecamatan Petang.

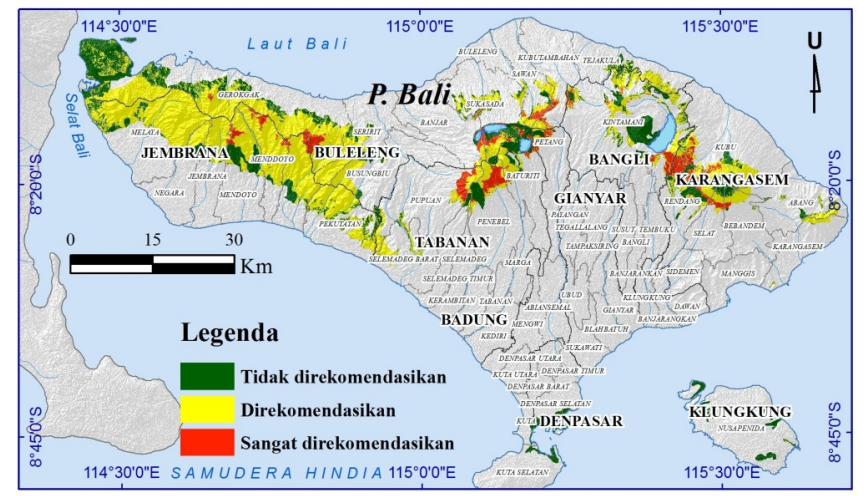

Gambar 11. Area lokasi rekomendasi eksplorasi tumbuhan

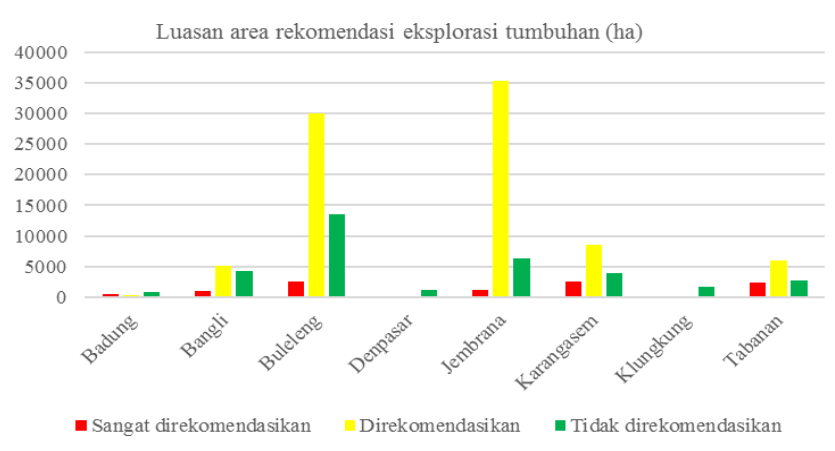

Gambar 12. Komposisi perbandingan luasan area eksplorasi setiap kabupaten di Bali.

Melihat peta arahan eksplorasi tumbuhan daerah Pulau Bali ini, memberikan gambaran bahwa lokasi tujuan eksplorasi masih sangat luas dan beragamnya alternatif lokasi yang masih belum banyak terungkap kekayaan biodiversitas tumbuhannya. Oleh karena itu, perencanaan kegiatan eksplorasi akan jauh lebih matang dan dasar penentuan lokasi yang selama ini masih banyak based on local knowledge dari masyarakat maupun petugas lapangan dapat dilengkapi dengan data lokasi rekomendasi eksplorasi tumbuhan, sehingga peluang mengumpulkan jenis tumbuhan baru yang belum terkoleksi maupun memiliki status konservasi yang terancam menjadi lebih tinggi.

\section{KESIMPULAN}

Kegiatan eksplorasi tumbuhan merupakan kegiatan fundamental dalam kegiatan konservasi ex situ. Salah satu tugas fungsi Kebun Raya "Eka Karya" Bali (KREKB) adalah melakukan eksplorasi tumbuhan asli Indonesia khususnya kawasan timur Indonesia yang berstatus terancam kepuna- 
han dan bernilai ekonomis tinggi akibat pengaruh kerusakan lahan dan perubahan penggunaan lahan. Perencanaan dalam menentukan lokasi eksplorasi tumbuhan sangat diperlukan dengan cara melihat karakteristik wilayah KREKB dan ekologi suatu kawasan yang akan dieksplorasi. Pendekatan spasial dengan menggunakan parameter tutupan vegetasi, penggunaan lahan, satuan bentuklahan, elevasi, dan historis eksplorasi sangat membantu menentukan wilayah yang belum tereksplorasi dan prioritas lokasi yang perlu dieksplorasi. Wilayah pegunungan di perbatasan antara Kabupaten Buleleng dan Jembrana, Bali bagian tengah, serta pegunungan di Kabupaten Karangasem merupakan area yang sangat direkomendasikan sebagai lokasi eksplorasi tumbuhan untuk dikonservasi di KREKB. Diharapkan dengan adanya peta rekomendasi lokasi eksplorasi ini, kegiatan eksplorasi tumbuhan dapat terencana dengan lebih baik sehingga perolehan material koleksi tumbuhan, khususnya koleksi baru dan tumbuhan yang terancam kepunahan, dapat meningkat. Kajian ini pun dapat menjadi rujukan untuk penentuan lokasi eksplorasi bagi Kebun Raya Indonesia lainnya, dengan catatan, modifikasi perlakuan parameter perlu dilakukan sesuai dengan karakteristik tipe lokasi masing-masing kebun raya.

\section{UCAPAN TERIMA KASIH}

Penulis mengucapkan terimakasih kepada unit Registrasi Koleksi, Balai Konservasi Tumbuhan Kebun, Raya "Eka Karya" Bali yang telah menyediakan data eksplorasi.

\section{KONTRIBUSI PENULIS}

Rajif Iryadi sebagai kontributor utama dan Agung Kurniawan sebagai kontributor anggota dalam penulisan karya ilmiah ini. Rajif Iryadi membuat ide, konsep, analisis data, dan penulisan naskah. Agung Kurniawan membantu menyediakan data-data terkait koleksi tumbuhan di Kebun Raya "Eka Karya" Bali dan penulisan naskah.

\section{DAFTAR PUSTAKA}

Antonelli A., C. Fry, R.J. Smith, S.J. Simmonds, P.J. Kersey, H.W. Pritchard, M.S. Abbo, C. Acedo, J. Adams, A.M. Ainsworth, B. Allkin, W. Annecke, S.P. Bachman, K. Bacon, S. Bárrios, C. Barstow, A. Battison, E. Bell, K. Bensusan, M. I. Bidartondo, R.J. Blackhall-Miles, J.S. Borrell, F.Q. Brearley, E. Breman, R.F.A. Brewer, J. Brodie, R. Cámara-Leret, R.C. Forzza, P. Cannon, M. Carine, J. Carretero, T.R. Cavagnaro, M.E Cazar, T. Chapman, M. Cheek, C. Clubbe, C. Cockel, J. Collemare, A. Cooper, A.I. Copeland, M. Corcoran, C. Couch, C. Cowell, P. Crous, M. da Silva, G. Dalle, D. Das, J.C. David, L. Davies, N. Davies, M.N. De Canha, E.J. de Lirio, S. Demissew, M. Diazgranados, J. Dickie, T. Dines, B. Douglas, G. Dröge, M.E. Dulloo, R. Fang, A. Farlow, K. Farrar, M.F. Fay, J. Felix, F. Forest, L.L. Forrest, T. Fulcher, Y. Gafforov, L.M. Gardiner, G. Gâteblé, E. Gaya, B. Geslin, S.C. Gonçalves, C.J.N. Gore, R. Govaerts, B. Gowda, O.M. Grace, A. Grall, D. Haelewaters, J.M. Halley, M.A. Hamilton, A. Hazra, T. Heller, P.M. Hollingsworth, N. Holstein, M.J.R. Howes, M. Hughes, D. Hunter, N. Hutchinson, K. Hyde, J. Iganci, M. Jones, L.J. Kelly, P. Kirk, H. Koch, I. KrisaiGreilhuber, N. Lall, M.K. Langat, D.J. Leaman, T.C. Leão, M.A. Lee, I.J. Leitch, C. Leon, E. Lettice, G.P. Lewis, L. Li, H. Lindon, J.S. Liu, U. Liu, T. Llewellyn, B. Looney, J.C. Lovett, Ł Łuczaj, E. Lulekal, S. Maggassouba, V. Malécot, C. Martin, O.R. Masera, E. Mattana, N. Maxted, C. Mba, K.J. McGinn, C. Metheringham, S. Miles, J. Miller, W. Milliken, J. Moat, P.G.P. Moore, M.P. Morim, G.M. Mueller, H. Muminjanov, R. Negrão, E. Nic Lughadha, N. Nicolson, T. Niskanen, R.N. Womdim, A. Noo- rani, M. Obreza, K. O’Donnell, R. O’Hanlon, J.M. Onana, I. Ondo, S. Padulosi, A. Paton, T. Pearce, O.A.P. Escobar, A. Pieroni, S. Pironon, T.A.K. Prescott, Y.D. Qi, H. Qin, C.L. Quave, L. Rajaovelona, H. Razanajatovo, P.B. Reich, E. Rianawati, T.C.G. Rich, S.L. Richards, M.C. Rivers, A. Ross, F. Rumsey, M. Ryan, P. Ryan, S. Sagala, M.D. Sanchez, S. Sharrock, K.K. Shrestha, J. Sim, A. Sirakaya, H. Sjöman, E.C. Smidt, D. Smith, P. Smith, S.R. Smith, A. Sofo, N. Spence, A. Stanworth, K. Stara, P.C. Stevenson, P.Stroh, L.M. Suz, B.B. Tambam, E.C. Tatsis, I. Taylor, B. Thiers, I. Thormann, C. Trivedi, D. Twilley, A.D. Twyford, T. Ulian, T. Utteridge, V. Vaglica, C. VásquezLondoño, J. Victor, J. Viruel, B.E. Walker, K. Walker, A. Walsh, M. Way, J. Wilbraham, P. Wilkin, T. Wilkinson, C. Williams, D. Winterton, K.M. Wong, N. Woodfeld-Pascoe, J. Woodman, L. Wyatt L, R. Wynberg, and B.G. Zhang (2020), State of the World's Plants and Fungi 2020, Royal Botanic Gardens, Kew, https://doi.org/10.34885/172.

Aplin, D. (2016), Chapter 3: No plant collection without a strategy or policy, in: J. Gratzfeld (ed), From Idea to Realisation: BGCI's Manual on Planning, Developing and Managing Botanic Gardens, 47-65, Botanic Gardens Conservation International (BGCI), Richmond, United Kingdom.

Badan Pusat Statistika Provinsi Bali (BPS Bali) (2021, Juni), Data geografis, Klimatologi dan Kawasan Hutan Wilayah Bali Tahun 2020. Diakses tanggal 17 Juni 2021 dari https://bali.bps.go.id/

Badzlina, A., I.S. Banuwa, A. Bintoro, and D. Duryat (2019), Composition analysis of vegetation in Sub-Sub DAS Khilau Kabupaten Pesawaran, Jurnal Ilmiah Biologi Eksperimen dan Keanekaragaman Hayati, 6(1), 50-54. doi: 10.23960/jbekh.v6i1.33

Botanic Gardens Conservation International (BGCI) (2012), International Agenda for Botanic Gardens in Conservation: 2nd edition, Botanic Gardens Conservation International, Richmond, UK.

Darma, I D. P., Sutomo, S.F. Hanum, A. Rahayu, and R. Iryadi (2021), Mengenal Koleksi Tematik Kebun Raya Eka Karya Bali dalam Sebuah Taman, LIPI Press, Jakarta.

Fathurahman, M. D. and R.Z. Maliki (2018), Evaluasi kesesuaian lokasi Bank BRI di wilayah Kantor Cabang Setiabudi Kota Bandung, Majalah Geografi Indonesia, 32(2), 184-197.

Goltenboth, F., K.H. Timotius, P.P. Milan, and J. Margraf (Eds.) (2006), Ecology of Insular Southeast Asia: the Indonesian archipelago, Elsevier.

Gross, M. (2018), Can botanic garden save all plants, Current Biology, 28, R1075-R1095.

Heywood, V.H. (2017), The future of plant conservation and the role of botanic gardens, Plant Diversity, 39, 309-313.

Havens, K., P. Vitt, M. Maunder, E.O. Guerrant, and K. Dixon (2006), Ex situ plant conservation and beyond. Bioscience, 56 (6), 525-531.

International Union for Conservation of Nature (IUCN) (2021), The IUCN Red List of Threatened Species, Version 2021-1, Diakses tanggal 18 Juni 2021 dari https://www.iucnredlist.org.

Kebun Raya "Eka Karya" Bali. (2015), Laporan Eksplorasi Kebun Raya "Eka Karya" Bali 2012-2015, BKT Kebun Raya "Eka Karya" Bali - LIPI, Tabanan.

Kebun Raya "Eka Karya” Bali. (2019), Registrasi Koleksi Tumbuhan Kebun Raya Bali, BKT Kebun Raya "Eka Karya" Bali - LIPI, Tabanan.

Malanson, G. P., L.M. Resler, D.R. Butler, and D.B. Fagre (2019), Mountain plant communities: Uncertain sentinels? Progress in Physical Geography: Earth and Environment, 43(4), 521-543.

Niu, Y., S. Yang, J. Zhou, B. Chu, S. Ma, H. Zhu, and L Hua (2019), Vegetation distribution along mountain environmental gradient predicts shifts in plant community response to climate change in alpine meadow on the Tibetan Plateau. Science of The Total Environment, 650, 505-514.

Pedrotti, F. (2012), Plant and Vegetation Mapping, Springer Science \& Business Media, Heidelberg.

Plants of the World Online (POWO) (2019), Plants of the World 
Online, Facilitated by the Royal Botanic Gardens, Kew, Published on the Internet, http://www.plantsoftheworldonline.org/ Diakses tanggal 18 Juni 2021.

Priyadi, A., C. Feng, M. Kang, and H. Huang (2018), Development of 10 single-copy nuclear DNA markers for Euchresta horsfieldii (Fabaceae), a rare medicinal plant, Applications in Plant Sciences, 6(9), e1178.

Purnomo, D. W., M. Magandhi, F. Kuswantoro, R.A. Risna, and J.R. Witono. (2015), Pengembangan koleksi tumbuhan kebun raya daerah dalam kerangka strategi konservasi tumbuhan di Indonesia, Buletin Kebun Raya, 18(2), 111-124.

Sanjaya, P.K.A. (2020), Hutan lestari, aspek sosial ekonomi yang mempengaruhinya, UNHI Press, Denpasar-Bali.

Setiawan, O. (2012), Analisis variabilitas curah hujan dan suhu di Bali. Jurnal Analisis Kebijakan Kehutanan, 9(1), 66-79.

Siringo Ringo R.S.L., W.S. Lestari, IW. Mudarsa, IM.R. Pendit, IG.W. Setiadi, C.I.M. Semarayani, A. Rahayu, A.S. Lỉaini, I.B.K. Arinasa, I.B.K Arsana, IW. Sumantera, and IW. Warnata (2019), 60 tahun Kebun Raya "Eka Karya" Bali (15 Juli 1959 15 Juli 2019), Balai Konservasi Tumbuhan Kebun Raya "Eka Karya" Bali - LIPI, Tabanan.

Smith, P. (2016), Preface, in: J. Gratzfeld (ed), From Idea to Realisation: BGCI's Manual on Planning, Developing and Managing Botanic Gardens, i, Botanic Gardens Conservation International (BGCI), Richmond, United Kingdom.

Sujarwo, W. (2013), Klasifikasi kelimpahan tumbuhan di Kecamatan Kintamani, Bali: Studi kasus usaha konservasi, Jurnal Manusia dan Lingkungan, 20 (30), 276-283.

Surya, M. I., M. Lalilati, I. Ekasari, Y. Nuraleni, S. Astutik, S. Normasiwi, A.R. Gumilang, D.I. Junaedi, Z. Mutaqien, D.R Nurdiana, W. Rahman, Destri, and A.H. Rozak (2013), Konservasi tumbuhan di Kebun Raya Cibodas sebagai penyelamat keanekaragaman hayati pegunungan di Indonesia, Lokakarya Nasional "Keanekaragaman Hayati sebagai Modal Dasar Dasar Pembangunan", 30-31.
Sutomo (2014), Eksplorasi Keberadaan Tumbuhan Langka Lokal di Bali, Jurnal Al-Azhar Indonesia Seri Sains dan Teknologi, 4, 253 -259 .

Sutomo, ID.P. Darma, A. Priyadi, W. Sujarwo, F. Kuswantoro, and R. Iryadi (2018), Ecology of Bedugul Basin Bali, SEAMEOBIOTROP, Bogor.

Tunc, A., G. Tuncay, Z. Alacakanat, and F.S. Sevimli (2019), GIS Based Solar Power Plants Site. Selection Using Analytic Hierarchy Process (AHP) In Istanbul, Turkey. International Archives of the Photogrammetry, Remote Sensing and Spatial Information Sciences - ISPRS Archives, 42(2/W13), 1353-1360.

van Zuidam, R.A. and F.I. van Cancelado, (1978), ITC Textbook of Photo-Interpretation Vol VII Chapter 6: Terrain Analysis \& Classification Using Aerial Photographs, ITC, Netherlands.

Verstappen, H. (2013), Garis Besar Geomorfologi Indonesia, Penerjemah: Sutikno, Gajah Mada University Press, Yogyakarta.

Wahyuni, S., S.F. Hanum, F. Kuswantoro, IM.R. Pendit, and H.E. Slamet (2017), Eksplorasi Flora Pengkayaan Koleksi Kebun Raya Gianyar-Bali, Lembaga Ilmu Pengetahuan Indonesia, Tabanan.

Warseno, T. and R. Iryadi (2015), Kajian botani, distribusi dan potensi jenis jenis dioscorea sebagai tanaman pangan alternatif di Bali. Seminar Nasional Biodiversitas, 293-297.

Whitten, A.J., T. Whitten, R.S. Soeriaatmadja, R.E. Soeriaatmadja, and S.A. Afiff (1996), Ecology of Java and Bali (Vol. 2), Oxford University Press, Singapore.

Widjaja, E.A., Y. Rahayuningsih, J.S. Rahajoe, R. Ubaidillah, I. Maryanto, E.B. Walujo and G. Semiadi (2014), Kekinian keanekaragaman hayati Indonesia, LIPI Press, Jakarta.

Winarna and H. Santoso (2009), Analisis potensi lahan melalui pendekatan sistem informasi Geografi dan Remote Sensing untuk pengembangan tanaman kelapa sawit di Provinsi Kalimantan Tengah, Jurnal Penelitian Kelapa Sawit 17: 98-107.

Zucca, A., A.M. Sharifi, A.G. and Fabbri (2008), Application of Spaasial Multi-Criteria Analysis to Site Selection for Local Park: A Case Study in The Bergamo Province, Italy. Journal of Enviromental management. 88 (4), 752-769. 